\title{
CHANGES IN THE CROPPING PATTERN AMONG THE AGRO ECOSYSTEMS IN TAMIL NADU
}

\author{
S. DEEPIKA ${ }^{1 *}$, \& M. JEGADESSAN ${ }^{2}$ \\ $1 *$ Senior Research Fellow, Department Of Social Science, Agricultural College and Research Institute, Kudumiyanmalai, Tamil Nadu \\ Agricultural University, India \\ ${ }^{2}$ Assistant Professor, Department Of Social Science, Agricultural College and Research Institute, Kudumiyanmalai, Tamil Nadu \\ Agricultural University, India
}

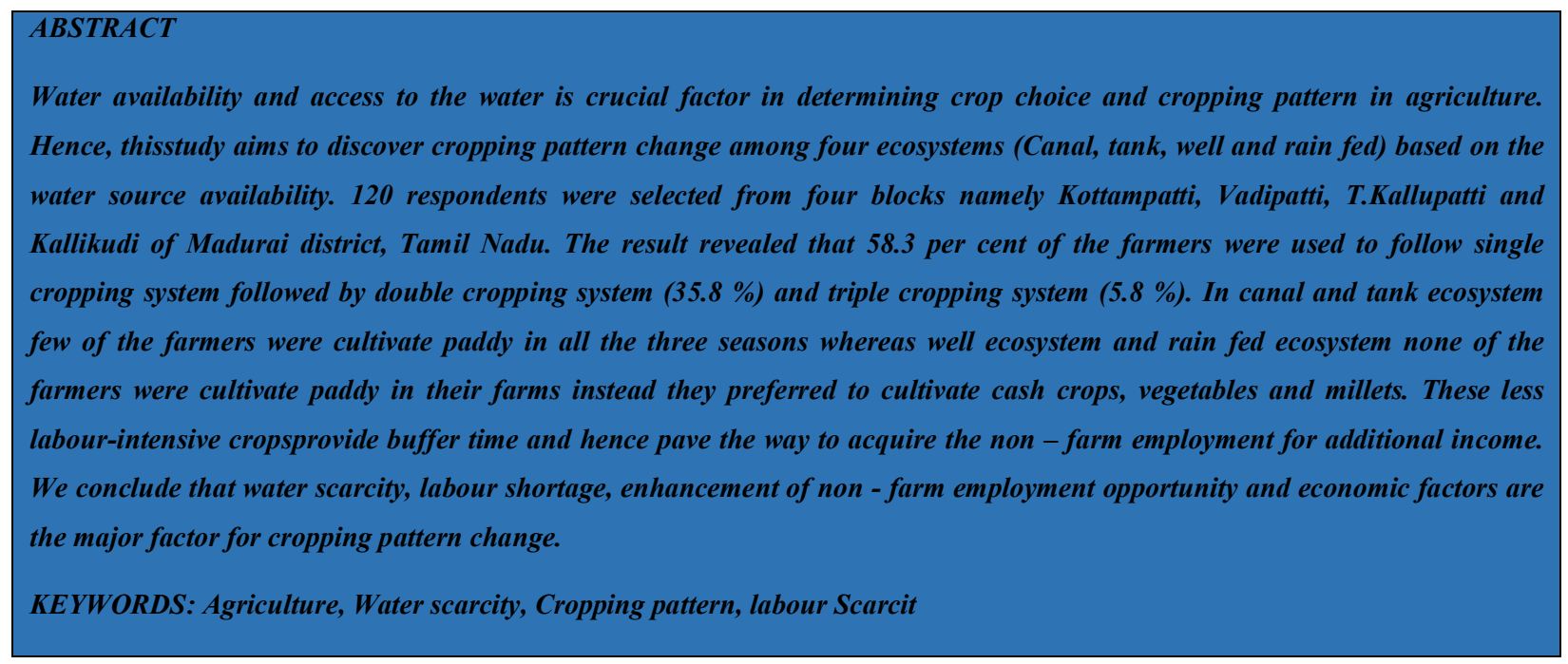

Received: Nov 30, 2020; Accepted: Dec 20, 2020; Published: Jan 08, 2021; Paper Id.: IJASRDEC20206

\section{INTRODUCTION}

After (1990s) agriculture has been abridged due to the appearance of globalization and liberalization.Remarkably, over the years, agriculture sector in India has been undergoingnoticeable changes with respect to area under cultivation, productivity, cropping pattern, land holding size \& pattern, use of technology, irrigation pattern, fertilizers \& pesticides usage, area underirrigationand use of high yielding variety of seeds. These are all the changes incite the farmers for their occupation into off and non - farm occupation which is giving surplus employment prospect to the people. The reason for development of non- farm activities was profitability of farming getting reduced. Apart fromprofit in farming, some of the reason for shifting into non - farm was employment prospects high in without agriculture sector (Chand and Srivastava, 2014) andcompared to manufacturing/ capitalist sector, consuming higher per capita productivity than farming (Rains and Fei, 1961).

Due to climatic factors, labour problem, land fragmentation and opportunities for non - farm activities are motivated farmers to go for changing their cropping pattern in order to suit the market trend. These alterations in the 
cropping pattern mostlyhappened due to augmentation in the prices of cash crops or non-food grains. After independence plenty of changes had been noted in respect of cropping pattern in India.According to Lobell etAl. (2011)andAnderson (2009) crop pattern change is not addressed specially, alterations in agriculture practices should be taken.

Major water source in India is canal, tank, open well and bore well.Irrigation is the most significant agricultural input in a humid monsoon country like India where rainfall is indeterminate, unpredictable and irregular. India cannot reachpersistentdevelopment in agriculture unless and until more than half of the cropped area is carried under definite irrigation. Due to low level of rainfall, cropping pattern in India has also changed.Earlier, people used to cultivate crop throughout the year (three seasons). Later, it was changed into two or one season per year because of water scarcity.

Labour scarcity is also one of the reasons for agrarian change. Reason for labour scarcity is low rainfall and emergence of non - farm activities. The farmers were cultivating less labour intensive crop due to low rainfall so they were moving into other opportunity for their livelihood. Family labour system has completelyvanished because of unwillingness among the family members especially youth to work in agriculture. They are looking fornon - farm employment opportunity. Non-farm employment leads to the people for rural and urban migration. Fragmentation of land is another area of concern as it is directly affect scale of operation and mechanisation. All the discussion we had above, clearly demonstrate that agriculture in Tamil Nadu under transition process. In this transition, changes in the cropping pattern have offered the choices to the farmers in non-farm and other entrepreneurial involvement(Agu, 2013). Considering importance of agrarian change and its effect on farmer's livelihood, this paper isintended to analyse the effect of cropping pattern change among four ecosystems, i.e., Canal, tank, well and rain fed, in life and livelihood among the farmers.

\section{METHODOLOGY}

Madurai district is selected as one the district that has all four ecosystems.It administratively divided into 13 blocks. The blocks were selected based on the water source availability. Block level statistical data reveals that tank irrigation is more prevalent in the Kottampatti block, canal irrigation dominantly practiced in the Vadipatti block, well irrigation is widespread in the T.Kallupatti block and rainfed cultivation is ubiquitous in the Kallikudi block were selected for this study.Potential study villages for each ecosystem were collected from the office of the Assistant Director of Agriculture at each block.Based on the suggestion and their experience it is decided to select 30 farmers from each block and 30 farmer respondent may come from three to five villages. The villages were identified based on the distance from the block headquarters. This is because road connectivity and access to the town is believed to influence the mobility of the rural households. Thus, each village was carefully selected from $5 \mathrm{~km}, 10 \mathrm{~km}$ and $15 \mathrm{~km}$ radius from the block headquarters and 10 respondents were selected from each village randomly from sample population. Hence, 30 respondents from each block and totally 120 respondents from all four blocks or four eco types were selected for this research. The following table (1) indicated that selected villages and corresponding blocks of Madurai district.

\section{Statistical Analysis}

A well-structured \& pre tested interview schedule was used to collect data by personal interview method. The following statistical tools will be used for the analysis and the interpretation of the data.

1. Percentage analysis 
2. Cumulative frequency

Table 1: Selection of blocks and villages

\begin{tabular}{|c|c|c|c|c|}
\hline S.No. & Ecosystem & Block & Village Name & No.of Respondents \\
\hline \multirow{3}{*}{1} & \multirow{3}{*}{$\begin{array}{l}\text { Canal } \\
\text { (Periyar Vaigai) }\end{array}$} & \multirow{3}{*}{ Vadipatti } & Aundipatti & 10 \\
\hline & & & Neerarthan & 10 \\
\hline & & & Kattakulam & 10 \\
\hline \multirow{3}{*}{2} & \multirow{3}{*}{ Tank irrigation } & \multirow{3}{*}{ Kottampatti } & Vellinipatti & 10 \\
\hline & & & Ayyapatti & 10 \\
\hline & & & Kunnarampatti & 10 \\
\hline \multirow{3}{*}{3} & \multirow{3}{*}{ Well Irrigation } & \multirow{3}{*}{ T. Kallupatti } & S Paraipatti & 10 \\
\hline & & & Thummanayakkanpatti & 10 \\
\hline & & & Keelapatti & 10 \\
\hline \multirow{3}{*}{4} & \multirow{3}{*}{ Rainfed } & \multirow{3}{*}{ Kallikudi } & Sivarakottai & 10 \\
\hline & & & Agathapatti & 10 \\
\hline & & & Maitaanpatti & 10 \\
\hline \multicolumn{4}{|l|}{ Total } & 120 \\
\hline
\end{tabular}

\section{RESULTS AND DISCUSSIONS}

\section{Demography Characteristics of Respondents}

The profile was collected to know the basic information about the respondents and its interconnection with other variables. All the results are interpreted using percentage analysis. The results stated that three- fourth $(75.80 \%)$ of the respondent's belonged to old farmers followed by 15.00 per cent in the middle aged farmers.Except rain fedecosystem, average age of the household heads were more than 50 where as in the rain fed ecosystem was about 46.80 per cent. During the field survey it was observed that attitude of younger generation towards agriculture is not positive and they would like to move away from the farming.

In other hand majority (95.84 \%) of the men household heads were involved in farming operations whereas few (4.16 \%) of the women headed households were involved in farming operations. In terms of educational status, One - fourth (24.10\%) of the respondents had education up to high school followed by primary school education (20.80\%), functionallyliterate (16.70\%), MiddleEducation (14.20\%), illiterate(9.20\%), higher secondary education (8.30\%) and collegiate education (15.80\%).

Table 2: Classification of household based on family size and labour force

\begin{tabular}{|l|l|l|l|l|l|l|}
\hline \multirow{2}{*}{ Eco System } & \multicolumn{3}{|l|}{ Average Number of household } & \multicolumn{2}{l|}{ Average Number Members in Labour force } \\
\cline { 2 - 7 } & Men & Women & Total & Men & Women & Total \\
\hline Canal & 2.06 & 1.96 & $\mathbf{3 . 9 6}$ & 2.00 & 1.93 & $\mathbf{3 . 8 6}$ \\
\hline Tank & 2.53 & 1.83 & $\mathbf{4 . 3 6}$ & 2.10 & 1.86 & $\mathbf{3 . 9 6}$ \\
\hline Well & 2.86 & 1.76 & $\mathbf{4 . 2 6}$ & 2.53 & 1.73 & $\mathbf{4 . 2 6}$ \\
\hline Rainfed & 2.03 & 1.63 & $\mathbf{3 . 2 3}$ & 1.83 & 1.63 & $\mathbf{3 . 2 3}$ \\
\hline
\end{tabular}

(Multiple responses)

It could be grasped from the Table 2 that average family size in the study area was around 4. It is the impact of successful population control campaign of Government of Tamil Nadu initiated in 1980s, and hence family size of rural Tamil Nadu 
noticeably came down to 4.14 from 6.76 in 1990s. This study is also confirmed this change over the time. Remarkably, available labour force per family is almost equal to family size. It means that if opportunity given, all the members in the family can participate in the work and contribute to the family income. The labour force in the study area had started shrinking due to demographic changes and male migration to the industrial sectors. The available work force is not showing interest in participating in agriculture and allied activities. They seem to be more attracted towards blue -collar employment elsewhere.

\section{Occupational Choice among the Respondents}

Aspiration of family members among the respondents attracted towards the non-farm opportunities was observed. Thus, occupation wise analysis was carried out to understand the trends in the occupational choice among the study respondents. Data were presented in the table. 3

Table 3: Dispersion of household head based on their occupational strategy

\begin{tabular}{|c|l|c|c|}
\hline S.No & \multicolumn{1}{|c|}{ Status } & Number & Per cent (\%) \\
\hline 1 & No occupation & 0.00 & 0.00 \\
\hline 2 & Daily wage alone & 0.00 & 0.00 \\
\hline 3 & Farming + Wage earners & 13.00 & 10.80 \\
\hline 4 & Farming (Cultivating own land and / or lease) & $\mathbf{9 4 . 0 0}$ & $\mathbf{7 8 . 3 0}$ \\
\hline 5 & Business (Self Employed) & 0.00 & 0.00 \\
\hline 6 & Salaried persons in government or private & 2.00 & 1.70 \\
\hline 7 & Farming + Business & 8.00 & 6.70 \\
\hline 8 & Farming + Service $\quad 3.00$ & 2.50 \\
\hline & $\quad$ Total & $\mathbf{1 2 0}$ & \\
\hline
\end{tabular}

It could be seen from the Table 3 that changes had occurred in choice of the occupations. Quite interestingly, more than the three fourth of household heads $(78.30 \%)$ primarily believe farming as sole source of income earning activities. Prolong experience in the farming, doing what they know and persistent to do farming may be reasons for this outcome. Land holding, poor education and lack of skill in non-agricultural works were also possible causes for this outcome. It was easy to conclude that household heads were predictably independent in choosing their livelihood choices. Slightly higher than one-fifth of ( 22 per cent) of the household heads were diversified to other occupations with farming. If we include sibling of the household's head in this analysis, the result will be completely different. As it observed that their son and daughters were considerably changed and diversified their livelihood portfolio based on their education, interest and opportunity available at local level.

\section{Land Possession access to the Land among the Respondents}

Results in the table 3 clearly showed that almost four-fifth of the households in the study area predominately depended on land for their livelihood. Access to the land alone does not guarantee better income as quantity and quality of the land does matter. Thus, analyse based on the land possession among the households were carried out the results are presented in the table 4 .

It could be observed from the above Fig 1 that nearly half of the households (47.60\%) were endorsed with less than 4 acres of land to till and toil for their livelihood. Another 52.50 per cent of the households were having more than 4.1 acre of lands.About one-third of the respondents (33\%) are small and marginal farmers and cultivating one crop per year. If landholding was 
segregated based on the caste affiliation (Table 4) and its corresponding social status and power relations, it was found that Backward Caste (BC) had an average of 6.20 acre of land followed by Most Backward Caste (MBC) household with 5.96 acre and Scheduled Caste (SC) household with 3.72 acres. Like Education, access to the land also plays crucial role in constructing sustainable livelihood for farming households.

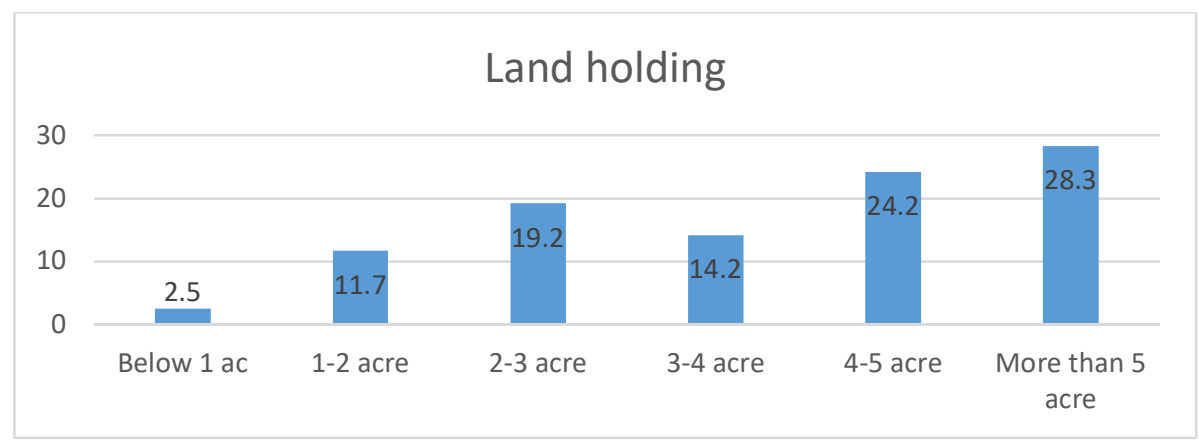

Figure 1: Distribution of farmers according to the land ownership $(n=120)$

Table 4: Classification of household based on caste status and access to the land

\begin{tabular}{|l|l|l|l|l|l|l|l|l|l|}
\hline \multirow{2}{*}{ Eco System } & \multicolumn{9}{|l|}{ BC } \\
\cline { 2 - 11 } & $\begin{array}{l}\text { No. } \\
\text { HH }\end{array}$ & $\begin{array}{l}\text { Land } \\
\text { holding }\end{array}$ & Income & $\begin{array}{l}\text { No. } \\
\text { HH }\end{array}$ & $\begin{array}{l}\text { Land } \\
\text { holding }\end{array}$ & Income & $\begin{array}{l}\text { No. } \\
\text { HH }\end{array}$ & $\begin{array}{l}\text { Land } \\
\text { holding }\end{array}$ & Income \\
\hline Canal & 17 & 14.11 & 55688 & 11 & 8.27 & 31363 & 2 & 2.5 & 15000 \\
\hline Tank & 23 & 3.61 & 23391 & 2 & 3.75 & 25000 & 5 & 2.6 & 19000 \\
\hline Well & 7 & 3.91 & 18291 & 12 & 6.07 & 19714 & 11 & 7.18 & 17636 \\
\hline Rainfed & 6 & 3.16 & 5930 & 8 & 5.75 & 10649 & 16 & 2.63 & 6314 \\
\hline $\begin{array}{l}\text { Total/ } \\
\text { Average }\end{array}$ & $\mathbf{5 3}$ & $\mathbf{6 . 1 9 7 5}$ & $\mathbf{2 5 8 2 5}$ & $\mathbf{3 3}$ & $\mathbf{5 . 9 6}$ & $\mathbf{2 1 6 8 1 . 5}$ & $\mathbf{3 4}$ & $\mathbf{3 . 7 2 7 5}$ & $\mathbf{1 4 4 8 7 . 5}$ \\
\hline
\end{tabular}

Data presented in the Table 4 showed that upper caste people had relatively better access to the land for cultivation when compare to Most Backward and Scheduled Caste households. Further, with relation to the access to irrigation upper Caste households predominately had their land under common irrigation systems like a canal and tank. Whereas the Scheduled Caste households had their land under rainfed condition followed by well irrigation.Since very few SC households have the land under canal and tank command area, they almost forced todepend on rainfall to cultivate the crops. Average income per acre of land for BC households was about Rs 4304/crop/annum, for MBC it was Rs 3638 and for SC it stood around Rs 3894. Cost of cultivation is in increasing trend, especially for labour and inputs, theywere preferred to cultivateless labour and input intensive and less water required crop like sorghum, grams and millets. On other hand, they were seeking the right opportunity to diversify their livelihood through non - farm opportunity in and around their residential area. This lineage slowly leads to domestic migration among the vulnerable communities like Scheduled Caste in the village.

As it was discussed earlier, access to land alone may not yield required benefit to run the family. The resources like water, labour and finance are critically important to decide on crop choice and livelihood diversification. Based on the access to the water their crop choice would differ and so their income. So, it is important to analyse availability and accessibility of the 
water to the respondents.

\section{Water Access and its Nexus with Crop Choice}

Irrigation is an important factor for cropping pattern change. Irrigation availability decided the crop choice per year. It could be seen from fig 2 that 75 per cent of the respondents had access to irrigation facilities like canal, tank and well. Farmers in the canal irrigated area were depended on the combined source of Periyar-Vaigai canal and open well for supplement irrigation throughout the cropping season.

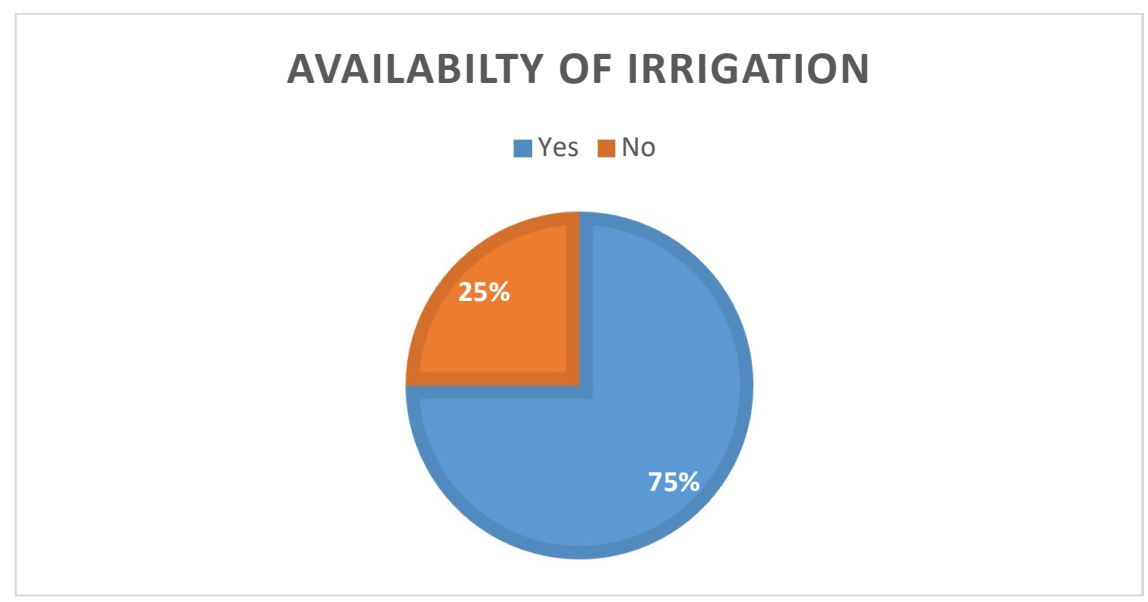

Fiureg 2: Distribution of farmers according to their irrigation status $\quad(n=120)$

In the case of tank farmers, they drew water from the irrigation tanks and provide supplement irrigation with their wells. Another 25 per cent of the farmer respondent solely depends on well only and they don't have any other source of irrigation facilities. They are always dependent on rainfall and are used to cultivate rainfed crop only.

Access to irrigation sources is completely different from the availability of water. It is understood that 75.00 per cent of the farm households had access to irrigation source like canal, tank and well. But the availability of water at the time of need is questionable. Farmers in the study area were shared their futile experience of erratic and defective system of water delivery from canal and tank. Thus, the famers in the study area were attempted to augment water necessary for crop cultivation through individualised well irrigation.Kazaz and Webster (2011) said that water obtainability is the keyfoundation of profitvagueness, it is applied to figure a stochastic optimization model in which the resource action depends on rainfall and irrigation.

\section{Augmentation of Ground Water Source for Crop Cultivation}

Due to the high density of tanks in the study area, subsistence food crops such as paddy, millets and pulses were planted at least until the mid-1990s. Poor maintenance, encroachment and siltation in the tank fed area (Jegadeesan and Fujita, 2009) led deterioration of tank and canal irrigated area. It triggered, the construction/installation of wells enhanced. This enabled farmers to change their crop choice from existence food crops to cash crops, because the later needs additional water, which can be attributed to the unsatisfactory performance of wells in the area. 
Table 5: Average pumping hours based on ecosystem

\begin{tabular}{|c|c|c|c|c|}
\hline \multirow{2}{*}{ S.No } & \multirow{2}{*}{ Year } & Canal & Tverage pumping hours based on ecosystem \\
\cline { 2 - 5 } & & 15.96 & 21.45 & 20.90 \\
Wumping hours per day \\
\hline 1 & 1990 & 15.35 & 17.01 & 16.75 \\
\hline 2 & 1995 & 14.21 & 09.01 & 12.23 \\
\hline 3 & 2000 & 10.04 & 02.10 & 07.25 \\
\hline 4 & 2005 & 07.80 & $\mathbf{0 0 . 5 0}$ & 03.30 \\
\hline 6 & 2010 & $\mathbf{0 5 . 3 0}$ & $\mathbf{0 0 . 7 5}$ \\
\hline
\end{tabular}

Due to unsatisfactory performance, farmers had spent to install bore or modernise their wells. Investment in the wells generates significant income benefit primarily but failed to provide it sustainably. Up to 2016, the pumping hours of canal, tank and well ecosystems were 5.3, 0.5 and 0.75 hours per day respectively(Table 5). Still now, most of the farmers are having wells but the pumping hours of water was reduced which is used only for household purpose but it is not sufficient to meet requirement of crop demand.

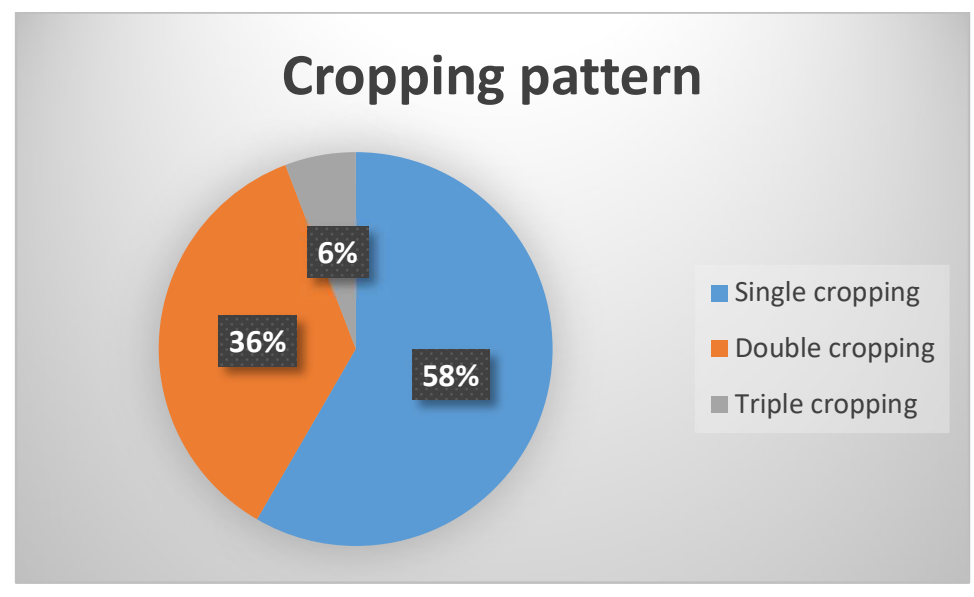

Figure 3: Distribution of farmers according to their cropping pattern $\quad(n=120)$

It could be seen from fig 3 that over 58.3 per cent of the farmers were used to cultivate single cropping system followed by double cropping system (35.8 \%) and Triple cropping system (5.8 \%). In the study area most of the farmers were cultivating single crop per season per year. Due to irregular monsoon and uncertainty water level in the canal and tank, fluctuating market price had forced the farmers to reduce their cropping intensity. In the early 1990s and late 1980s, Periyar-Vaigai canal might supply water for at least 160 days and irrigation tank would provide water for 120 days and availability of ground water was also reasonably good. Hence, the farmers in the study area opined that they used to cultivate triple cropping per year in the canal, tank and well irrigated eco system. According to Morton, J. F. (2007) Commercialization of agriculture is generated through water scarcity, changing labour force towards non- agricultural sector and economic factors. These influencesincrease into agrarian change, which a primary factor of cropping pattern changes.

It could be known from the Table 5 that all the eco systems were deviated or changed from the conventional cropping pattern. In the Periyar-Vaigai command area, the farmers were practicing "Paddy-Paddy-Pulse/Cotton" cropping pattern 
predominantly. This pattern has been imperilled due to irregularity in discharging water in the canal from the dam. Irregular and unpredictable nature of canal water has driven the farmers to invest in ground water extraction. In the first season, when the canal water available, 80 per cent of the respondents in canal eco system were cultivated paddy, in the second season it was only 16 per cent and no one cultivated paddy in the third season. The same trend was visualised in the remaining ecosystem.

In tank ecosystem, mostly farmers were cultivated vegetables (brinjal, tomato onion \& chilli), cash crops (coconut, cotton \&peanut) and millets because of low rainfall and labour scarcity. Few of the farmers were cultivate paddy in all the three seasons whereas well ecosystem and rain fed ecosystem none of the farmers were cultivate paddy in their farms instead they preferred to cultivate cash crops, vegetables and millets. Because of urbanisation and road connectivity most of the farm households converted to vegetables which procure good market price in the urban centre.Bidyadhar Majhi and Awadhesh Kumar (2018) stated except cereals and pulses, farmers in India have graduallyinvolved in the production of marketable crops such as vegetables, fruits, oilseeds, and fibres etc. for the period of 2002-03 to 2012-13. Therefore, it is not that farmers are dropping interest in farm activities and shifting to the non-farm sector for examine of employment, rather they are more intensively shifting towards growing of cash/ commercial crops such as oilseeds, fruits, vegetables, spices, etc. from the traditional non-cash/ noncommercial crops such as than cereals and pulses. Thechange in crop production in the direction of cash crops that are climate resistant in addition to less labour intensive (DeFriesR..et al., 2016). By means of, there has been a change in most important cereal that is consumed.

With respect to diversified farmers majority of them shifted their traditional cropping pattern (paddy + vegetable crops (brinjal, tomato, chilli) or paddy + paddy) to new cropping pattern (vegetable crops (brinjal, tomato, chilli) + vegetable crops (brinjal, tomato, chilli), coconut + vegetable crops (brinjal, tomato, chilli) /pulses, sugarcane, coconut + banana + maize ,maize + vegetable crops (brinjal, tomato, chilli)) and vegetables (brinjal, tomato, chilli) + millets (kudiraivalli, varagu, ragi).

\section{CONCLUSIONS}

This study concludes that all the ecosystemsweredramatically changed from their respective traditional cropping pattern. This pattern has been imperilled due to irregularity of rainfall. Farmers in the canal and tank command area lost their hope due to inconsistency in delivering water and made them as less reliable irrigation sources. It forced the farmers to think about dependable source of water and they started developing their ground water source through open and bore well. Since tank and canal water is relatively free and did not attract additional cost, crop cultivation was remunerative. When common irrigation system lost their charm, individual farmers mobilised required funds to invest in the development of well. Due to climatic factors and over exploitation of ground water, pumping hours were also drastically down over the period. Hence, they could not able to cultivate the crop as they did in earlier. All these factors prompted the farmers to change their existing cropping pattern. In the case of canal and tank eco system ,a small number of the farmers were cultivate paddy in all three season whereas well ecosystem and rain fed ecosystem none of the farmers were cultivate paddy in their farms instead they preferred to cultivate cash crops, vegetables and millets. The farmers in these ecosystems were predominantly cultivating vegetable crops which attract reasonable market price in the nearby urban centre. The changed cropping pattern and corresponding agrarian change were directly and indirectly influenced the employment opportunities. It was observed that earlier labour-intensive crop such as paddy, sugarcane and cotton were frequently cultivated in all the ecosystems. Because of uncertainty of water availability, the farmers were forced to change their 
cropping pattern from paddy to millet and vegetables.So, less labour-intensive crops led the situation of unemployment for small \& marginal farmers and agricultural labourers. It can be concluded thatwater stress, labour scarcity andenhancement of non - farm employment opportunitiesare the major factors responsible for cropping pattern change.

Table 5: Changes in cropping pattern based on the ecosystem

\begin{tabular}{|c|c|c|c|c|c|c|c|c|c|c|c|c|}
\hline HAH & & $\operatorname{sinal}$ Ledoy & & & Pnk Learyzt & & & dincosy & & & Santed spater & \\
\hline Na. & కcanoal I & Scanon II & Scaion III & కcanoaI & Scaion II & Scaion III & Scasea I & Scanon II & Scason III & Seavont & Scaton III & Scanen III \\
\hline T & Fanty & Collen & Sarefliti & Hinisy & Tomalo & Fillow & Cusumiter & Fillow & Hitant & Rises & Real grath & Merix \\
\hline 2 & Fanty & Codich & $\sin x$ & Ganger & Fanty & $\operatorname{Mns} x$ & Peanul & $\operatorname{Min} x$ & Tnilow & Callan & Thisen & $\operatorname{men}$ \\
\hline 3 & Thanty & Codia: & Sirebluin & Teanul & Fanty & Givan & Collan & $\operatorname{Mns} x$ & Fillow & Calis & Thillow & Thlow \\
\hline 4 & Haninti & Carre & Thillow & Crions & Mrax & Fillow & Pranul & Fillew & Finlow & Mars & Callan: & Thlow \\
\hline 5 & Twaty & Haremi & Sireflinh & Criva, & Malla & Teanil & C्वाक् & Pranil & T्याइए人 & Sieghing & Tanul & Thillow \\
\hline 6 & Thanty & $\operatorname{Max}$ & Thiser & Ganger & Chath & Thilew & $\operatorname{Mnx}$ & Crine & Tomalo & Mrox & Serghine & Tillow \\
\hline 7 & Tanty & Panty & Sireghilin & Cinumiter & Tomalo & Cinat & Codica: & Peanil & $\operatorname{Manx}$ & $\operatorname{Mrnx}$ & Serphin & Tillow \\
\hline 8 & Panity & Callon & Mrax & Codica & Gountril & Fillow & Hrixgil & Fallow & $\operatorname{Mnx}$ & Sarghing & Cangelly & Fallow \\
\hline 9 & Panty & Cancen & Sireghinit & Pesiul & Panty & Thlaw & Hringl| & Fillow & $\operatorname{Mnx}$ & Saeghing & Gamplly & Fillow \\
\hline 10 & Panty & Panty & Sieghifit & Panul & Tanty & Thilsw & Pranul & $\operatorname{Mns} x$ & Thish & Calicen & Sirghing & Fillow \\
\hline$\pi$ & Panty & Codican & Sireghinit & Cusumer & Chill & Hitanti & $\operatorname{Mns}$ & Fillow & Fillow & Calicen & Sieghint & Thillow \\
\hline 12 & Panty & Conlan & Sireghint & Tomalo & Panty & $\operatorname{Mnx} x$ & Harana & Tomato & Hinifil & Kusinaval & Siseghuit & Fillow \\
\hline $\mathrm{TH}$ & Panty & Panty & Sireghint & Chilli & Cusumber & Hitant & Cosinter & Tomalo & Hinify & Kuninavat & sireghint & Fillew \\
\hline 14 & Fanty & Contan & $\operatorname{Mon}$ & Hringli & Tomito & Criss & $\operatorname{Manx}$ & Fanly & Cone & Collicen & Red gram & Thlaw \\
\hline 15 & Fanty & Codten: & & Mallet: & $\mathbf{M}$ & fallow & & Heranti & friow & $\operatorname{Mins}$ & Segefont & Then \\
\hline
\end{tabular}

Table 5: Changes in cropping pattern based on the ecosystem (Continued)

\begin{tabular}{|c|c|c|c|c|c|c|c|c|c|c|c|c|}
\hline \multirow{2}{*}{$\begin{array}{l}\text { HF } \\
\text { Na. }\end{array}$} & \multicolumn{3}{|c|}{ Ganal Eetgyatem } & \multicolumn{3}{|c|}{ Tank Econyatem } & \multicolumn{3}{|c|}{ Wall Ecosyytem } & \multicolumn{3}{|c|}{ 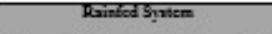 } \\
\hline & Scaion I & \begin{tabular}{|c|} 
Seasan III \\
\end{tabular} & Sesaon III & ScanoaI & Scason II & Sesion III & Scaion I & Sczasn II & Scaion III & Secion I & Sesaon III & Scanon III \\
\hline 16 & Conla: & $\operatorname{Man} x$ & Fillow & Avenii & Teanil & Ganger & Fillow & Thillow & Chilli & $\min x$ & Fives & Fillow \\
\hline 15 & Panily & Panty & Sefgum & Cocienti & Cocienil & Cocienti & Fillow & Callan & Fillow & Gountrie & $\operatorname{Mnx}$ & Thillow \\
\hline 18 & Panty & Panty & $\min x$ & Callan & Cocienif & Panty & Fallow & Contan & Thillow & Gountril & $\operatorname{Min} x$ & Thillow \\
\hline TS & $\operatorname{Max}$ & sugurans & Fillow & Tranul & Funty & Collisa & Fillow & Chint & Sireghilit & Sareghilit & Fillow & Fillow \\
\hline 20 & Thing & Conta: & Maxix & Prant & Thises & Contian & Fillow & Fanul & Fillow & Kusinamiti & Sarfitur & Gangelly \\
\hline 21 & Gim & Fillow & Fillew & Chilli & Thag & Collis & Fillow & Mallei & Fillow & Kustinimalli & \begin{tabular}{|l|l} 
Red gnimi \\
\end{tabular} & Thillow \\
\hline 22 & Panty & Fillow & Sireghilin & Grios & Panty & Fallow & Fillow & Laman & Fillow & Gangelly & Fallow & Thillow \\
\hline 23 & Tanty & Fillow & Sireghint & Callan & Tanul & Fillow & Fillow & Kusiravali & Fillow & $\operatorname{Mnx}$ & Fillow & Fillow \\
\hline 24 & Collan & Fillow & siegluin & Panty & Panul & Thllow & Fillow & Gingelly & Fillow & Kusingivalti & 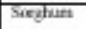 & Trillow \\
\hline 25 & Painty & C्dican & Sarghuth & Cinution & Panty & Fillow & Fillow & 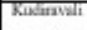 & Fillow & $\operatorname{Mrax}$ & Kusanvali & Fallow \\
\hline 26 & C्वाक & Heringl & Sieghint & Collan & Prant & Thillow & Fillow & Sacthin & Fillow & Gown grm & Codich & Fillow \\
\hline 27 & Fanty & Harmai & Fillow & Calian & Fanty & Thillow & Fillow & Sareghin & Fillow & THillow & Kusinvalt & Fillow \\
\hline 25 & Paily, & Fillow & (nimes & Pentil & Panty & Fillow & Fillow & Gangelly & Fillow & Kusirativiti & Fillow & Fillow \\
\hline 2s & Fanty & Fillow & Fillow & Haremi & Panty & Thillow & Fingex & Kunsinvali, & Fulaw & C्वाiक & Kusiravali & Thisw \\
\hline 30 & Fanty & $\operatorname{mos} x$ & Fillow & Contis & Panty & Thillow & Filsow & Contion & Fillow & Thlow & Fillow & Filaw \\
\hline
\end{tabular}

\section{REFERENCES}

1. Anderson, K., 2009. Asia's role in stabilizing food and agricultural prices. Bouis, H.E. and Haddad, L.J., 1990. Agricultural commercialization, nutrition, and the rural poor.

2. Agu, P. 2013. Rural Non-farm Livelihood Diversification and poverty Reduction in Nigeria, School of management, University of Plymouth, U.K. 
3. Bidyadhar Majhi* and Awadhesh Kumar. (2018) “Changing cropping pattern in Indian agriculture”,Journal of Economic \& Social Development, Vol. - XIV, No. 1, 2018.

4. Chand, R and Srivastava, S.K. (2014): “Changes in the Rural Labour Market and their Implications for Agriculture”, Economic and Political Weekly, Vol. 49, No. 10.

5. Chakraborty, Samarpan, and Debabrata Basu. "Homestead Gardening: An Emerging Venture Towards Achieving Food Security \& Nutritional Security-A Study of Selected Areas of West Bengal." International Journal of Applied and Natural Sciences (IJANS) ISSN (P) (2018): 2319-4014.

6. DeFries, R., Mondal, P., Singh, D., Agrawal, I., Fanzo, J., Remans, R. and Wood, S. (2016). Synergies and trade-offs for sustainable agriculture: Nutritional yields and climate-resilience for cereal crops in Central India. Global Food Security, 11, pp.44-53.

7. Goyal, Megha, and Urmil Verma. "WHEAT YIELD PREDICTION USING WEATHER BASED STATISTICAL MODEL IN NORTHERN ZONE OF HARYANA." International Journal of Humanities and Social Sciences (IJHSS) 7.4, Jun - Jul 2018; 47-50

8. JegadeesanM and KFujita, (2009). Aspects of Tank Irrigated Agrarian Economy in Tamil Nadu, India: A Study of Three Villages, Working paper No.79. CSEAS, Kyoto,Japan

9. Kazaz, B., S. Webster. 2011. The impact of yield - dependent trading costs on pricing and production planning under supply 404 uncertainty.Manuf.Ser.Oper.Manag.13(3)-417.

10. VASHISHAT, CHANDAN SHARMA\& NISHA. "PREVALANCE OF ENDOPARASITES IN HOUSE CROW (CORVUS SPLENDENS) FROM DIFFERENT AGROECOSYSTEMS OF LUDHIANA, PUNJAB." International Journal of Agricultural Science and Research (IJASR) 7.4, Aug 2017, 577-582

11. Lobell, D.B., Schlenker, W. and Costa-Roberts, J., 2011. Climate trends and global crop production since 1980. Science, 333(6042), pp.616-620.

12. Lokesh, Jain. "Identification of problems of a village in Haryana using participatory agro-ecosystem analysis." International Journal of Agricultural Science and Research (IJASR) 5.5 (2015): 261-269.

13. Rains, G and Fei, JC H (1961): “A Theory of Economic Development”, The American Economic Review, Vol. 51 , No. 4. 